\title{
DOCUMENTING ABUNDANCE AND USE OF UNDERUTILIZED PLANT SPECIES IN THE MID HILL REGION OF NEPAL
}

\author{
Rajib Khanal, Arbindra Timilsina, Chandra P. Pokhrel ${ }^{1}$ and Ram Kailash P. Yadav*1 \\ School of Natural Resources and Bio Environment P. (Ltd.), P.O. Box 23383, Kathmandu \\ ${ }^{1}$ Central Department of Botany, Tribhuvan University, Kirtipur, Kathmandu \\ Email: rkp.yadav@cdbtu.edu.np
}

\begin{abstract}
Around the world, many communities depend on plant species that are outside the mainstream of agricultural research and development. These species are also known by various names, such as 'underutilized crops' 'neglected crops, poor people's crops' or 'third order crops'. More recently, they have been designated as crop for the future agriculture. Changing human perception and custodian, changing food habits, influence of globalization are the major factors leading to low priority to the local crop products. The study of underutilized plant species of the mid hill region is an attempt to highlight the food, fruits, vegetables, pulses and medicinal plants; and their mode of use by the local people. The study was conducted in two VDCs; Siddeshwor of Palpa and Hastichaur of Gulmi districts. A total of 52 plant species belonging to 27 families were recorded to be used frequently by the people of Siddeshwor and Hastichaur VDCs. Declining consumption of these local crop varieties at local level and low demand in the local market due to eroding traditional knowledge are main reasons for the farmers being unwilling to grow these crops.
\end{abstract}

Key words: Underutilized crops, neglected crops, genetic resources, agrobiodiversity, traditional knowledge, mid hill region.

\section{INTRODUCTION}

Agricultural biodiversity is a strategic asset for poor communities living in harsh environments and represents a source of livelihood options to improve their quality of life in terms of income, food security and health (Sthapit and Padulosi 2012). It is well established that biodiversity conservation and maintenance of associated ecosystem services are vital for human well being (Beaunount et al. 2011). Approximately 75,000 species of plants worldwide are believed to be edible (Walters and Hamilton 1993). Among them, about 30 crop species provide $95 \%$ of the worlds' food energy whereas over 7,000 species have been known to be used for food and are both partly or fully domesticated (Williams and Haq 2000). Overdependence on a few plant species exacerbates many acute difficulties faced by communities with regard to food security, nutrition, health, ecosystem sustainability and cultural integrity (Jaenicke and Hoschle-Zeledon 2006). Most of these plants are important locally or regionally only, and are known as 'minor', 'neglected', 'underexploited' and 'orphan' species, 
or 'underutilized crops' or 'undervalued crops', 'poor people's crops' or 'third order crops'. More recently, they have been designated as crop for the future agriculture (Pratap 1990).

The underutilized crops were once more widely grown but are now falling into disuse for various agronomic, genetic, economic, or cultural factors. In general, they are characterized by much less genetic improvement than the major crops but they are being lost because they are less competitive. In addition, these crops remain inadequately characterized and, until recently, have been largely ignored by researchers despite being valuable genetic resources. However, they are important for the subsistence of local communities, are maintained by socio-cultural preferences and traditional uses. Recently, there is an increasing realization among researchers, development practitioners and the general public regarding the positive role played by these neglected and underutilized species, not only in food security and improving people's livelihoods but also due to greater range of nutritional options (Padulosi et al. 2009). In addition, they are locally well adapted to marginal land and constitute an important part of the local diet, providing valuable nutritional elements (e.g. protein, vitamins and minerals) and spices, often lacking in staple crops (IAEA 2004). Yet they may represent our most valuable potential resource for the future. Moreover, underutilized crops in particular have received little investment from research institutions and development agencies (World Bank 2007).

Agriculture is the mainstay of hill's and mountain's economies in Nepal. Hills and mountains represent unique habitats or niches and great opportunities for promoting specific nichebased farming system or agrobiodiversity. Some local cultivars considered as underutilized or neglected crops can ensure sustainable production and contribute to improve livelihood of poor farmers. Many neglected and underutilized species are nutritionally rich. The erosion of these species can have immediate consequences for the nutritional status and food security of the poors (CGIAR 2010). Besides, they are less susceptible to climate change effects and diseases compared to improved varieties (Jarvis et al. 2008). Many of these groups and their breeds are nutritionally rich and adapted to low input agriculture (Thies 2000). These species hold great genetic diversity, and vast heritage of indigenous knowledge is linked to these species (Frison et al. 2000). Furthermore, these crops are now underutilized and becoming neglected which can be cultivated with less agricultural inputs on marginal lands in hills and mountain areas. Since the cultures and rituals are handed down from generation to generation, traditional knowledge is also transmitted in the same way. Such knowledge needs to be studied and documented. The documentation of underutilized plants and traditional knowledge on their utilization can be useful in devising strategies to check the loss and erosion of these valuable genetic resources. The aim of the present paper is to explore the underutilized plants of the mid hill region of Nepal through their documentation along with their use values in the local community based on their traditional knowledge.

\section{MATERIALS AND METHODS}

\section{Study site}

The study was conducted in two Village Development Committees (VDCs), viz. Siddheshwor VDC (83 $22^{\circ} 14.17^{\prime}$ ' E to $27^{\circ} 56^{\prime}$ $33.9^{\prime}$ ' $\left.\mathrm{N}\right)$ of Palpa and Hastichaur VDC $\left(83^{\circ} 14^{\prime}\right.$ $6.31^{\prime \prime}$ E to $28^{\circ} 7,52.93^{\prime \prime} \mathrm{N}$ ) of Gulmi district of mid hill region of Nepal. Map of the study areas is given in Fig. 1. Siddheshwor and Hastichaur VDCs, resembling in geographical locations, are characterized by three bio-geographical zones staggered from the temperate zone to tropical zone. As a typical feature of the hills, narrow river valleys are interspersed between mountain ranges

ECOPRINT VOL 21, 2014 
and spurs. The average minimum and maximum temperature varies from $23^{\circ} \mathrm{C}$ to $4.1^{\circ} \mathrm{C}$, respectively, and mean annual rainfall is over 1900 $\mathrm{mm}$. Varied altitude, topography, status of soil and climatic conditions favor high species richness and support different types of forests.

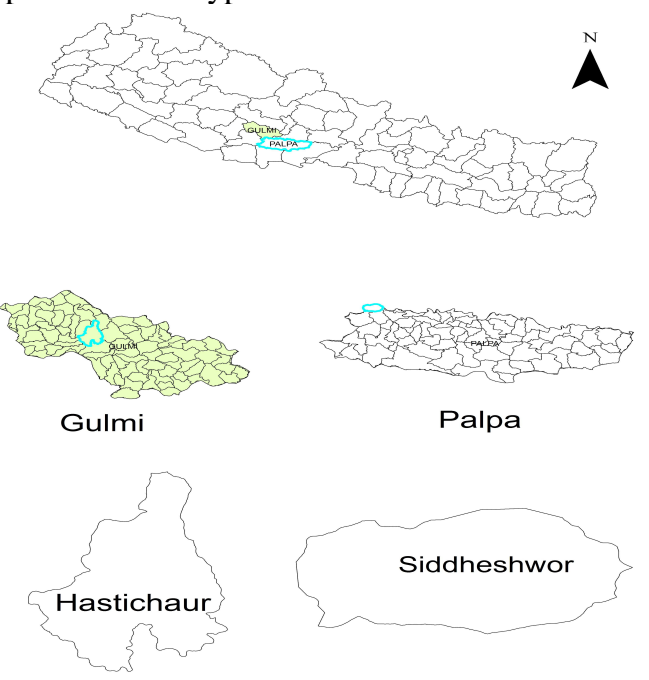

Fig. 1. Map of the study area showing studies VDCs.

\section{Data collection}

Both primary and secondary sources of information were used. Field surveys were carried out in both VDCs during the month of JuneSeptember 2013 to document information on different aspects of underutilized plant species such as traditional use, current practice, the method of preparation of food items and local names of such species harvested from private land and the nearby forest. Structured and semi-structured questionnaires were applied for community survey. Both male and female participants were involved during the field survey. In some cases, the edibility of plant parts was ascertained by personally eating cooked vegetables and prepared food items as bread and pickles, etc. Key informant interview was also conducted with the local key persons such as VDC secretaries, school teachers and lead farmers. Consumers and retailers of local market were also interviewed regarding underutilized plants and their prospect for commercial purpose.

\section{RESULTS AND DISCUSSION}

Both study areas are rich in underutilized and neglected plant species. Majority of the households depend largely upon their marginal land to grow and collect the fruits, grains, vegetables, and nuts as well ingredients for preparing pickles and spices. This is possible because most of the respondents of study areas are well aware and rich in indigenous knowledge about beneficial use of the plants.

Many domesticated or semi-domesticated underutilized plants cultivated by indigenous people not only determine their agricultural system, but also influence their food habit and way of life.

Such plants have received limited agronomic attention, hence their full potential has not been realized. Underutilized plant species in the study areas with their scientific name, local name (Nepali name), parts used and their uses (mode of use) are presented in Table 1. During the present study, information was collected on 52 species belonging to 27 families. Leguminosae was found to be the most common family with 7 species. Other important families were Gramineae, Cucurbitaceae (6 species each), Rutaceae (5 species), Chenopodiaceae, Cruciferae, Myrtaceae, Umbelliferae (2 species each). Parts of these plant species; seed, fruit, tuber, leaf, stem, twigs, pod and root are mainly used for consumption. Seeds of Fagopyrum esculentum, Paspalum scrobiculantum, Setaria italic, Sorghum vulgare. Echinocloa crus-galli are used for pan cake and are also consumed as fruits. The fruits of species Myrica esculenta, Aegle marmelos, Aesandra butyraceae, Phyllanthus emblica are highly demanded in the market at a large scale. The spicy seed and plant part of Perilla frutescens, Sesamum oriental, Cannabis sativa, Cuminum cyminum and Coriandrum sativum are also demanded in the market at large scale and with higher price. Highly nutritive vegetables such as Moringa oleifera, 
Dryopteris cocheleata, Asparagus racemosus and Momordica balsamina have also soaring demand in the urban area and market center. The study revealed that most of the underutilized plants recorded in the study area are used for multipurpose such as food, fruit, medicine, religious purpose, vegetables, oil extraction and pickle. Seeds of those species are mostly consumed as food, pulse, pickle; and leafy vegetables are cooked as boiled or fried. Some of the pulses are also found in the study area as underutilized species viz. Vigna umbellate, Macrotyloma uniflorum, Vigna mungo, Glycine max which are used for various purposes such as medicine and oil extraction. Macrotyloma uniflorum is consumed to cure stone in kidney.

Table 1. Neglected and underutilized plant species found in the Siddeshwor and Hastichaur VDCs and their local use.

\begin{tabular}{|c|c|c|c|c|c|}
\hline SN & Botanical Name & $\begin{array}{l}\text { Nepali } \\
\text { Name }\end{array}$ & Family & $\begin{array}{c}\text { Plant parts } \\
\text { use }\end{array}$ & Local uses (Mode of use) \\
\hline 1. & $\begin{array}{l}\text { Fagopyrum esculentum } \\
\text { Moench }\end{array}$ & Phapar & Polygonaceae & Seeds & Used as a pan cake, fodder \\
\hline 2. & $\begin{array}{l}\text { Eleusine coracana }(\mathrm{L} .) \\
\text { Gaertn. }\end{array}$ & Kodo & Gramineae & Seeds & $\begin{array}{l}\text { Pan cake, Beverages, fodder, } \\
\text { porridge }\end{array}$ \\
\hline 3. & Panicum miliaceum L. & Cino & Gramineae & Seeds & $\begin{array}{l}\text { Pan cake, Beverages, fodder, } \\
\text { porridge }\end{array}$ \\
\hline 4. & $\begin{array}{l}\text { Setaria italica }(\mathrm{L} .) \\
\text { Beauvois }\end{array}$ & Kaguno & Gramineae & Seeds & $\begin{array}{l}\text { Pan cake, Beverages, fodder, } \\
\text { porridge }\end{array}$ \\
\hline 5. & $\begin{array}{l}\text { Perilla frutescens (L.) } \\
\text { Britton }\end{array}$ & Silam & Lamiaceae & Seeds & Used as a pickle \\
\hline 6. & Amaranthus viridis $\mathrm{L}$. & Latte dana & Amaranthaceae & $\begin{array}{l}\text { Leaves, } \\
\text { seeds }\end{array}$ & Used as vegetable, sweets \\
\hline 7. & Chenopodium album $\mathrm{L}$. & Bethe & Chenopodiaceae & $\begin{array}{l}\text { Leaves, } \\
\text { seeds }\end{array}$ & As vegetables and pickles \\
\hline 8. & $\begin{array}{l}\text { Ipomoea batatas }(\mathrm{L} .) \\
\text { Lam }\end{array}$ & $\begin{array}{l}\text { Sakhara } \\
\text { khand }\end{array}$ & Convolulaceae & Tuber & $\begin{array}{l}\text { Eaten raw or roasted used in } \\
\text { religious occasions }\end{array}$ \\
\hline 9. & Sesamum orientale L. & Til & Pedaliaceae & Seeds & $\begin{array}{l}\text { Used to make pickles and } \\
\text { religious occasions to } \\
\text { worship }\end{array}$ \\
\hline 10. & $\begin{array}{l}\text { Vigna umbellata } \\
\text { (Thunb.) Ohwi \& Ohashi }\end{array}$ & Masyan & Leguminosae & Seeds & As a pulse \\
\hline 11. & Dioscorea alata $\mathrm{L}$. & Ghar tarul & Dioscoreaceae & $\begin{array}{l}\text { Stem, twigs } \\
\text { fruit }\end{array}$ & $\begin{array}{l}\text { As vegetable and sometime } \\
\text { by boiling }\end{array}$ \\
\hline 12. & $\begin{array}{l}\text { Colocasia esculenta (L.) } \\
\text { Schott }\end{array}$ & Gaba & Araceae & $\begin{array}{l}\text { Leaves and } \\
\text { tuber }\end{array}$ & As vegetable \\
\hline 13. & $\begin{array}{l}\text { Macrotyloma uniflorum } \\
\text { (Lam.) Verdc. }\end{array}$ & Gahat & Leguminosae & Seeds & $\begin{array}{l}\text { Used as pulses, fodder and } \\
\text { medicine for curing stone }\end{array}$ \\
\hline 14. & $\begin{array}{l}\text { Benincasa hispida } \\
\text { (Thunb.) Cogn }\end{array}$ & Kubindo & Curcurbitaceae & Fruit & $\begin{array}{l}\text { As vegetable, used to prepare } \\
\text { pickle and sweets }\end{array}$ \\
\hline 15. & Phaseolus vulgaris L. & Asare simi & Leguminosae & $\begin{array}{l}\text { Pod and } \\
\text { seeds }\end{array}$ & Vegetable and pulses \\
\hline
\end{tabular}




\begin{tabular}{|c|c|c|c|c|}
\hline 16. Lathyrus sativus L. & Khesari & Leguminosae & Seeds & Pulses and as fodder \\
\hline 17. Brassica nigra (L.) Koch & Rayo & Cruciferae & Leaves & Used as a vegetables \\
\hline $\begin{array}{l}\text { 18. Sechium edule (Jacq.) } \\
\text { Sw. }\end{array}$ & Skush & Curcurbitaceae & $\begin{array}{l}\text { Twigs, fruit } \\
\text { and root }\end{array}$ & Vegetables \\
\hline 19. Moringa oleifera Lam. & Sahinjan & Moringaceae & $\begin{array}{l}\text { Leaves, } \\
\text { pods }\end{array}$ & $\begin{array}{l}\text { Used as vegetable and } \\
\text { sometimes as medicine and } \\
\text { biofuel }\end{array}$ \\
\hline $\begin{array}{l}\text { 20. Myrica esculenta Buch- } \\
\text { Ham.ex D. Don }\end{array}$ & Kaphal & Myricaceae & Fruit & Fruit \\
\hline $\begin{array}{l}\text { 21. Aegle marmelos (L.) } \\
\text { Correa }\end{array}$ & Bel & Rutaceae & $\begin{array}{l}\text { Leaves and } \\
\text { fruit }\end{array}$ & Medicinal and religious value \\
\hline $\begin{array}{l}\text { 22. Aesandra butyraceae } \\
\text { (Roxb.) Baehni }\end{array}$ & Chyuri & Sapotaceae & Fruit & $\begin{array}{l}\text { As fruit and seeds used to } \\
\text { prepare ghee }\end{array}$ \\
\hline 23. Phyllanthus emblica L. & Aamala & Euphorbiaceae & Fruit & $\begin{array}{l}\text { Fruits, Source of vitamin c } \\
\text { and as medicine }\end{array}$ \\
\hline $\begin{array}{l}\text { 24. Citrus maxima (Burm. } \\
\text { ex Rumph.) Merr }\end{array}$ & Bhogate & Rutaceae & Fruit & Fruit \\
\hline $\begin{array}{l}\text { 25. Syzygium cumini (L.) } \\
\text { Skeels }\end{array}$ & Jamun & Myrtaceae & Fruit & Fruit and medicinal purpose \\
\hline $\begin{array}{l}\text { 26. Dryopteris cocheleata } \\
\text { (D. Don) C. Chr. }\end{array}$ & Niuro & Aspidiaceae & Stem & As vegetable \\
\hline $\begin{array}{l}\text { 27. Trichosanthes dioica } \\
\text { Roxb. }\end{array}$ & Parvar & Cucurbitaceae & Fruit & Used as a vegetable \\
\hline $\begin{array}{l}\text { 28. Curcuma angustifolia } \\
\text { Roxb. }\end{array}$ & Besar & Zingiberaceae & Root & $\begin{array}{l}\text { Used in vegetable and as } \\
\text { medicine }\end{array}$ \\
\hline $\begin{array}{l}\text { 29. Vigna mungo }(\mathrm{L} .) \\
\text { Hepper }\end{array}$ & Mas & Leguminosae & Seeds & Used as a pulses \\
\hline 30. Cucurbita pepo L. & Pharsi & Cucurbitaceae & $\begin{array}{l}\text { Twigs and } \\
\text { fruit }\end{array}$ & As vegetable \\
\hline 31. Annona squamata L. & Sitaphal & Annonaceae & Fruit & Used as a fruit \\
\hline 32. Cannabis sativa $\mathrm{L}$. & Bhang & Cannabaceae & Seed & To make pickle \\
\hline 33. Ricinus communis L. & Ander & Euphorbiaceae & Fruit & Fruit \\
\hline $\begin{array}{l}\text { 34. Asparagus racemosus } \\
\text { Willd. }\end{array}$ & Kurilo & Liliaceae & $\begin{array}{l}\text { Twigs and } \\
\text { stem }\end{array}$ & $\begin{array}{l}\text { As medicine, vegetable and } \\
\text { used as religious value }\end{array}$ \\
\hline 35. Spinacia oleracea L. & Palungo & Chenopodiaceae & Leaves & Used as vegetable \\
\hline $\begin{array}{l}\text { 36. Citrus aurantifolia } \\
\text { (Christ.) Swingle }\end{array}$ & Kagati & Rutaceae & fruit & $\begin{array}{l}\text { As medicine and source of } \\
\text { vitamin c }\end{array}$ \\
\hline 37. Citrus limon (L.) Burn f. & Nibuva & Rutaceae & Fruit & $\begin{array}{l}\text { As medicine and source of } \\
\text { vitamin c }\end{array}$ \\
\hline 38. Cuminum cyminum L. & Jira & Umbelliferae & Seeds & Used as condiments \\
\hline 39. Citrus junos Tanka & Kali jyamir & Rutaceae & Fruit & Used as fruit \\
\hline 40. Raphanus sativus L. & Mula & Crucifereae & $\begin{array}{l}\text { Stem and } \\
\text { leaves }\end{array}$ & As vegetable \\
\hline
\end{tabular}




\begin{tabular}{|c|c|c|c|c|}
\hline 41. Vicia faba L. & Bakula & Leguminosae & $\begin{array}{l}\text { Pods and } \\
\text { seeds }\end{array}$ & Used as vegetable and pulses \\
\hline 42. Glycine $\max$ (L.) Merr. & Bhatmas & Leguminosae & Seeds & $\begin{array}{l}\text { As vegetable pulses and for } \\
\text { oil extraction }\end{array}$ \\
\hline 43. Psidium guajava $\mathrm{L}$. & Amba & Myrtaceae & Fruit & $\begin{array}{l}\text { Used as fruit and to make } \\
\text { juice }\end{array}$ \\
\hline $\begin{array}{l}\text { 44. Litchi chinensis } \\
\text { (Gaertn.) Sonner }\end{array}$ & Lichi & Sapindaceae & Fruit & As a fruit \\
\hline 45. Coriandrum sativum L. & Dhaniya & Umbelliferae & $\begin{array}{c}\text { Leaves and } \\
\text { seeds }\end{array}$ & As condiments \\
\hline 46. Capsicum annuum L. & Khursani & Solanaceae & Fruit & As spicy condiments \\
\hline 47. Juglans regia L. & Okhar & Juglandaceae & Fruit & As fruit and oil extraction \\
\hline 48. Hordeum vulgare L. & Jau & Gramineae & Seeds & $\begin{array}{l}\text { Beverage, used in baking } \\
\text { industries and religious } \\
\text { purpose }\end{array}$ \\
\hline $\begin{array}{l}\text { 49. Luffa cylindrica (L.) } \\
\text { Roem }\end{array}$ & Ghiu toria & Cucurbitaceae & Fruit & Used as vegetable \\
\hline $\begin{array}{l}\text { 50. Momordica balsamina } \\
\text { L. }\end{array}$ & Barela & Curcurbitaceae & Fruit & Used as vegetable \\
\hline 51. Sorghum vulgare Pers. & Junelo & Gramineae & Seeds & Used as food after frying \\
\hline $\begin{array}{l}\text { 52. Echinocloa crus-galli } \\
\text { (L.) Beauvois }\end{array}$ & Sama & Gramineae & Seeds & Used as rice \\
\hline
\end{tabular}

Neglected plant species can be cultivated in marginal land or the fallow land (Williams and Haq 2000). They can be easily grown in the rain fed land or non-irrigated land so they are also called drought resistant species. Underutilized plant species provide more option for dietary diversity that can help smallholder farmers to collect food and earn more diet and nutrition. Majority of respondent expressed that they don't give much priorities to these neglected crops although these crops can be grown in marginalized or upland area. In addition, it is found that there is no use of any chemical fertilizer and pesticides to these crops. Therefore, underutilized crops are more safe and hygienic than that of commercially cultivated crops with high agricultural inputs.

Percentage of underutilized herb species is markedly more $(50 \%)$, followed by trees $(23 \%)$, climbers and creepers (19\%) and shrubs (8\%) (Fig. 2).

68

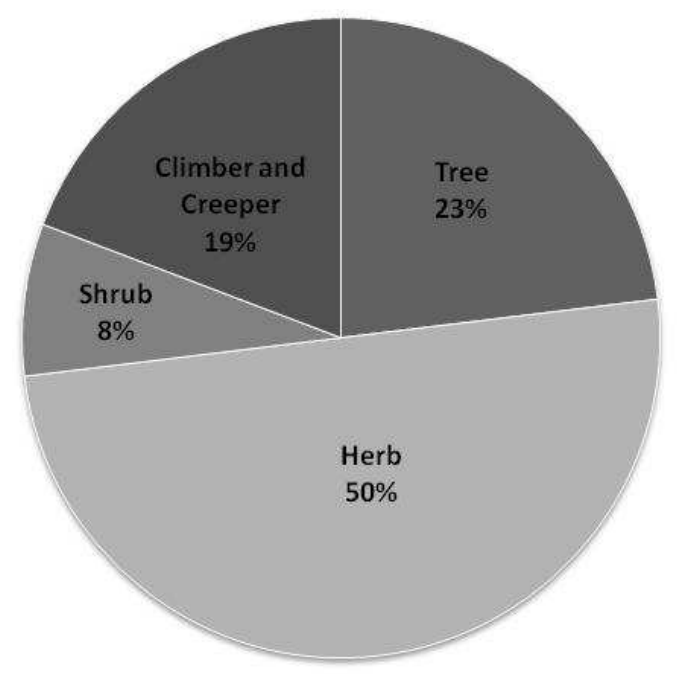

Fig. 2. Proportion of underutilized crops by habit type in the study area.

The results demonstrated that a total of 52 species were found as underutilized species in the study area; among those are $32 \%$ fruit, $31 \%$ seeds, $27 \%$ all part, $6 \%$ tubers and roots and only $4 \%$ leaves according to parts consumed by the local

ECOPRINT VOL 21，2014 
communities (Fig. 3). Uses of different parts of these plants by the local people in the study area are mostly similar to those used by other communities of Nepal (Srish et al. 2011, Khanal et al. 2013, Pant and Yadav 2013).

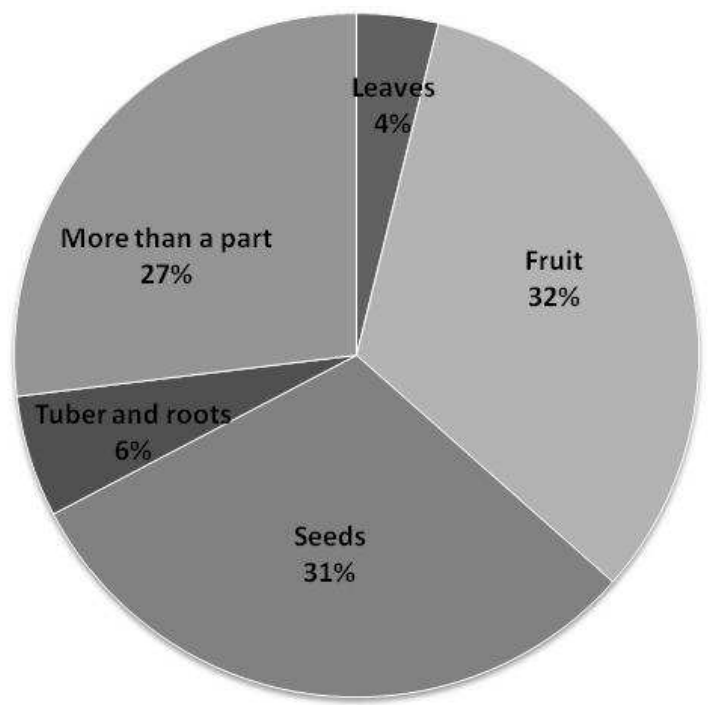

Fig. 3. Proportion of underutilized crops by parts used in the study area.

The present study also documented the use pattern of these plant species as follows: vegetable $(40.38 \%)$, and then followed by fruits $(21.15 \%)$, food $(19.23 \%)$, medicinal $(11.54 \%)$ and pulse (7.69\%) (Fig. 4). However, some plants have multipurpose utility too.

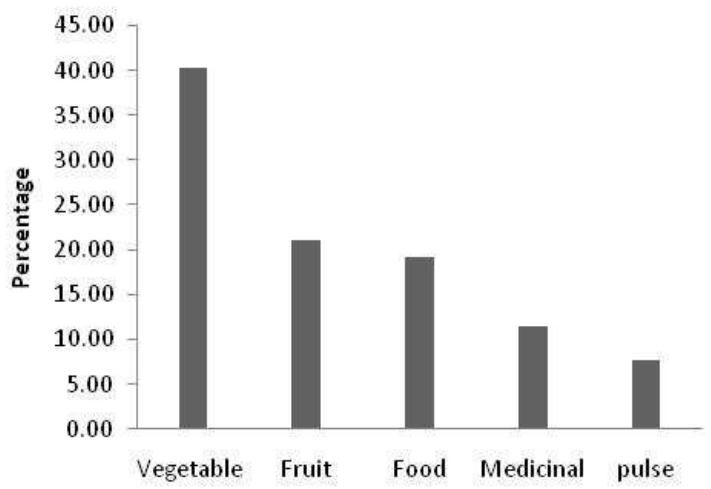

Fig. 4. Use pattern of underutilized plant species in the study area.
Out migration appeared to be a serious issue in the region rendering large number of farm area left abandoned. That has posed a threat on loss of many local useful species. Abandonment of traditional crops/cultivars means a loss of agrobiodiversity that remains 'lesser known' or 'unknown' to outside community and isolated distinct pocket areas (Sing et al. 1997). Agriculture practice of finger millet was mixed cropping system with other crops including maize, beans and soya beans. Villagers were found to cultivate these species on upland fields that were more important for the subsistence of the people. Most of the arable land of the study area were non-irrigated, which is very common farming system of mid hill, Nepal. These fields produced millet, sorghum, barley, buckwheat, soya beans, vegetables, and root crops as well as upland rice. Peasants eat these foods at least amount, and often these products are usually mixed with barley and sometimes buckwheat and millet. Production of these crops has decreased sharply with increasing imported food and seed items.

The local people have their own definition of underutilized crop species as "crops that are not regularly used at home, cannot be treated as food for guests due to their social inferiority and have poor marketing opportunities". These crops are considered as inferior [poor man's] foods.

Some people recalled that, traditionally, these species contributed significantly to the well-being and livelihood of their households. Despite the general notion that underutilized crops are neglected for specific socio-economic reasons, the role of these species used by indigenous farming communities becomes extremely important when reducing risks and adapting to adversity caused by climate changes. Many of these species are well adapted to stress conditions of extreme environments and form part of subsistence farming systems (Jarvis et al. 2008). 
Underutilized species hold great genetic diversity and enormous indigenous knowledge is linked to these species (Frison et al. 2000). Despite the fact that the importance of these plants to rural peoples' subsistence, economy and culture has long been reported (Kunwar and Adhikari 2005), these species are often found growing in marginal habitats (Pastor et al. 2006). Lack of awareness of these crops among the locals, changing human perception, food habits, high status on imported food items are also the leading factors of low priority to the local crop products. Declining consumption of these local crop varieties at local level and low demand in the local market are main reasons for the farmers' unwillingness to grow these crops.

\section{CONCLUSIONS}

Underutilized or neglected crops are 'underexploited' and 'orphan' species, and they are also under-researched crops. Promoting local underutilized plant species is one alternative for conservation of agrobiodiversity and it will prove successful in improving the food sufficiency and economic well being of poor farmers in mid hill of Nepal such as Gulmi and Palpa districts. Farmers are reluctant to grow these crops because of low return, poor market value, unaware about their nutritional and environmental value. Therefore, there should be intensified promotion and development of these neglected crops and channelize the surplus products to the market through the value addition process. These underutilized and neglected species can play a crucial role in the food security, income generation and diversify food culture of the rural poor. Also conservation of these crops is one of the best options for genetic resources conservation, which is the main asset of marginality and poor community living in the hill and mountain regions. Therefore, indigenous knowledge regarding farming systems and underutilized plant species also need to be protected and promoted through research and development programmes.

\section{ACKNOWLEDGEMENTS}

The authors extend their sincere gratitude to the ethnic communities and local people of Hastichaur VDC of Gulmi district and Siddeshwor VDC of Palpa district for their generous cooperation during field study. The local farmers are acknowledged for providing information about the plant use and the local traditional healers are acknowledged for providing information of medicinal use of plants.

\section{REFERENCES}

Beaunount, L.J., A. Pitam, S. Perkins, N.E. Zimmermann, N.G. Yoccoz and W. Thuiller. 2011. Impacts of climate change on the world's most exceptional ecoregions. PNAS 108:2306-2311.

CGIAR. 2010. Neglected and Underutilized Species. Interim Office of the Consortium of the CGIAR (Consultative Group on International Agricultural Research) Centers. FAO. Rome, Italy.

Frison, E., H. Omont and S. Padulosi. 2000. GFAR and International Cooperation on Commodity Chains. Synthesis paper for presentation to the GFAR-2000 Conference, Dresden, Germany, May 21-23, 2000.

IAEA. 2004. Genetic improvement of underutilized and neglected crops in low income food deficit countries through irradiation and related techniques: Proceedings of a Final Research Coordination Meeting organized by the Joint FAO/IAEA Division of Nuclear Techniques in Food and Agriculture and held in Pretoria, South Africa, 19-23 May 2003.

Jaenicke, H. and I. Hoschle-Zeledon. 2006. Strategic Framework for Underutilized Plant Species Research and Development: with 
Reference to Asia and the Pacific and SubSaharan Africa. International Center for Underutilized Crops, Sri lanka and Global Facilitation Unit for Underutilized Plants, Rome, Italy, p. 33.

Jarvis, A., H. Upadhyaya, C.L. Gowda, P.K. Agrawal and S. Fujisaka. 2008. Climate change and its effect on conservation and use of plant genetic resources for food and agriculture and associated biodiversity for food security. Thematic Study for the SoW Report on PGRFA, FAO, Rome, Italy.

Khanal, R., C.P. Pokhrel and R.K.P. Yadav. 2013. Some wild plants and local use in mid hill region of Nepal. Journal of Institute of Science and Technology, Tribhuvan University. 18(2):93-97.

Kunwar, R.M. and N. Adhikari. 2005. Ethnomedicine of Dolpa district, Nepal: The plants, their vernacular names and uses. Lyonia 8(1):43-49.

Padulosi, S., B. Mal, S. Bala Ravi, J. Gowda, K.T.K. Gowda, G. Shanthakumar, N. Yenagi and M. Dutta. 2009. Food security and climate change: role of plant genetic resources of minor millets. Indian Journal of Plant Genetic Resources 22(1):1-16.

Pant, G. and R.K.P. Yadav. 2013. Plant resource and utilization: a case study in Kanchanpur district, far-western Tarai, Nepal. Ecoprint 20:89-96.

Pastor, S., B. Fuentealba and M. Ruiz. 2006. Analysis of National and International Policies that Enable or Inhibit the Wider Use of Underutilized Plant Species for Food and Agriculture in Peru. Global Facilitation Unit for Underutilized Species, Italy.

Pratap, T. 1990. Exploring under-exploited crops of Himalaya Mountain Agriculture: Chenopods. In: Mountain Agriculture and
Crop Genetic Resources. (eds.) Riley, K.W., G.C. Mateo, G.C. Hawtin and R. Yadav. Oxford and IBH Publishing Co. Pvt. Ltd., New Delhi, pp. 165-183.

Sing, G.S., K.S. Rao and K.G. Saxena. 1997. Energy and economic efficiency of the mountain farming system: a case study in the north western Himalaya. Journal of Sustainable Agriculture 9:25-49.

Srish O., C.P. Pokhrel and R.K.P. Yadav. 2011. Plant diversity in homegardens and their use value in two villages of Rupandehi district, western Nepal. Ecoprint 18:85-90.

Sthapit, B. and S. Padulosi. 2012. On-farm conservation of neglected and underutilized crops in the face of climate change. In: On Farm Conservation of Neglected and Underutilized Species: Status, Trends and Novel Approaches to Cope with Climate Change. Proceedings of An International Conference, Frankfurt, 14-16 June, 2011. p. 31 .

Thies, E. 2000. Promising Underutilized Species: Crops and Breeds. GTZ, Germany.

Walters, M. and A. Hamilton. 1993. The Vital Wealth of Plants. WWF-World Wild Fund for Nature, Gland, Switzerland.

Williams, J.T. and N. Haq. 2000. Global Research on Underutilized Crops. An assessment of current activity and proposal for enhanced cooperation. International Center for Underutilized Crops, Southampton, UK.

World Bank. 2008. World Development Report 2008. Agriculture for Development. The World Bank, Washington DC, USA. 